\title{
Synthesis, characterization, and in vitro evaluation of novel polymer-coated magnetic nanoparticles for controlled delivery of doxorubicin [Retraction]
}

\begin{abstract}
Akbarzadeh A, Zarghami N, Mikaeili $\mathrm{H}$, et al. Synthesis, characterization, and in vitro evaluation of novel polymer-coated magnetic nanoparticles for controlled delivery of doxorubicin. Nanotechnol Sci Appl. 2012;5:13-25.
\end{abstract}

The Editor-in-Chief and Publisher of Nanotechnology, Science and Applications wish to retract the published article.

Concerns were raised about the level of similarity between the published article and another article published by the same authors in the International Journal of Nanomedicine titled 'Preparation and in vitro evaluation of doxorubicin loaded $\mathrm{Fe} 3 \mathrm{O} 4$ magnetic nanoparticles modified with biocompatible copolymers' (http://dx. doi.org/10.2147/IJN.S24326). Following a review, it was determined the level of text matching between the two articles was unacceptable. In addition, it was found there was an unacceptable level of image duplication between the same two articles and the findings and conclusions in the present study were no longer supported.

The affected figures within the present article are:
- Figure 2 is the same as Figure 1 in the International Journal of Nanomedicine article

- Figure 3 is the same as Figure 3C in the International Journal of Nanomedicine article

- The MTT assay results in Figure 5 are the same as those presented in the MTT assay results in Figure 6 of the International Journal of Nanomedicine article

- Figure $6 \mathrm{~B}$ is the same as Figure 7D in the International Journal of Nanomedicine article

- Figure 7A is the same as Figure 8 in the International Journal of Nanomedicine article

- Figure $8 \mathrm{~A}$ is the same as Figure $9 \mathrm{~A}$ in the International Journal of Nanomedicine article

- Figure 9A is the same as Figure $12 \mathrm{~A}$ in the International Journal of Nanomedicine article

- The optical images in Figure 12A, B and C are the same as those presented in the optical images in Figure 15A, $\mathrm{B}$ and $\mathrm{C}$ of the International Journal of Nanomedicine article

Our decision-making was informed by COPE's retraction guidelines. The authors cooperated throughout the process and agree with the decision to retract. The authors wish to apologize for this error. 


\section{Publish your work in this journal}

Nanotechnology, Science and Applications is an international, peerreviewed, open access journal that focuses on the science of nanotechnology in a wide range of industrial and academic applications. It is characterized by the rapid reporting across all sectors, including engineering, optics, bio-medicine, cosmetics, textiles, resource sustainability and science. Applied research into nano-materials, particles, nano-structures and fabrication, diagnostics and analytics, drug delivery and toxicology constitute the primary direction of the journal. The manuscript management system is completely online and includes a very quick and fair peer-review system, which is all easy to use. Visit http://www.dovepress.com/testimonials.php to read real quotes from published authors.

Submit your manuscript here: https://www.dovepress.com/nanotechnology-science-and-applications-journal 